\title{
DOI: https://doi.org/10.24297/jac.v17i.8767
}

\section{How variations in concentrations of metal ions and suspended solids downstream}

\section{river Rwabakazi in Uganda can be used to study pollution}

\author{
Mukasa-Tebandeke, I.Z1 ; *Karume, I.; Ssebuwufu, J.; Wasajja, H. Z4; Nankinga, R4 ; Habimana, M¹ \\ ${ }^{1}$ Department of Chemistry, Faculty of Science, Kabale University, Uganda
}

${ }^{2}$ Chemistry Department, School of Physical Sciences, College of Natural Sciences, Makerere University, Uganda

${ }^{3}$ University of Kisubi, Uganda

${ }^{4}$ Departments of Earth Sciences, Wesleyan University, Connecticut USA

${ }^{*}$ Corresponding author

\begin{abstract}
Pollution is affecting river Rwabakazi in the Nile basin; its effects are reflected by high turbidity, $\mathrm{pH}$, total suspended solids, (TSS), electrical conductivity, metal ions concentrations, and low concentration of dissolved oxygen $\left(\mathrm{DO}_{5}\right)$. In this study, we report the variations in selected physicochemical parameters of waters of the Rwabakazi river. Turbidity, $\mathrm{pH}$, concentrations of selected metal ions, $\mathrm{TSS}$, and $\mathrm{DO}_{5}$ of water sampled from three selected sites on the river in Kabale were very high. Mean $\mathrm{DO}_{5}$ fell from $96 \pm 2 \mathrm{mg} / \mathrm{L}$ to $86 \pm 1.5 \mathrm{mg} / \mathrm{L}$ downstream. The mean $\mathrm{pH}$ fell from $7.8 \pm 0.03$ to $7.6 \pm 0.04$, showing the removal of basic components. The turbidity dropped from370 \pm 3 NTU to $305 \pm 2$ NTU, showing that the haziness of water decreased. The concentration of iron(II) fell from $320 \pm 0.3 \mathrm{mg} / \mathrm{L}$ to $291 \pm 0.2 \mathrm{mgL}^{-1}$ indicating the fair extent of heavy metal ions downstream. The TSS decreased from $330 \pm 5 \mathrm{mg} / \mathrm{L}$ to $300 \pm 5 \mathrm{mg} / \mathrm{L}$, and concentrations of calcium and magnesium ions also decreased, providing evidence for self-purification. The available data suggests that river Rwabakazi is polluted as a result of poor agricultural practices, erosion, and flash flooding. Further studies on nutrient and pesticide pollution of this river need to be carried out, and trees should be planted on steep open surfaces to minimize erosion.
\end{abstract}

Keywords: Dissolved oxygen, Turbidity, Total suspended solids, Electrical conductivity, Concentration of metal ions, Erosion.

\section{Introduction}

Environmental resources are goods and services. Goods are traded in market, and the non-traded goods provide livelihood value to rural populations. Environmental goods include timber, logs, poles, grass, wood fuel, beeswax, bees honey, fish, wildlife, minerals and water, gum, rattan, medicinal plants and edible fruits and plants. Environmental services are ecological functions such as micro climatic regulation, carbon sequestration and storage, soil conservation, filtration of effluent, watershed protection, recreational amenities, and habitat for valuable biological resources (Lange, et al. 2003).

The Nile River basin is a unique environment that has played a significant part in world history. Today it provides a home and sustenance to tens of millions of people among the world's poorest. Extreme poverty is linked to the environmental resources degeneration, yet these resources significant global impact. As a result, adverse environmental trends are undermining many of the attempts by the riparian nations to make a transition towards sustainable economic development. Deforestation and soil erosion can increase vulnerability to drought and lead to increased sedimentation and greater flood risks downstream, while sediments also accumulate in wetlands and reservoirs. Urbanization and industrialization lead to increased runoff and pollution that harm downstream water users. The main threats to basin-wide water quality are insufficiently treated domestic, urban 
and industrial wastes, non-point-source pollution from pesticide and fertilizer residues, siltation and sedimentation, increased salinity and wetlands loss. Increasingly, serious waterborne diseases are prevalent throughout the basin. Toxic and hazardous mining wastes represent dangers in some local areas. The costs of these threats are invariably born by downstream users. Inferior water quality has a disproportionately large impact on poor households in rural areas and urban slums, where access to uncontaminated water supplies is often limited. The poor are more likely to live in marginal or less desirable areas, such as along polluted waterways and heavily polluted agricultural drains in irrigated areas, in degraded watersheds, and in the vicinity of sewage treatment facilities and wastewater disposal sites. Their propensity to become sick is correspondingly greater, with negative impacts on their work and educational opportunities. The $\mathrm{pH}$ of surface water often lies between 6 and 7.5; but rivers are characterized by high sediment loads attributed to erosion caused by extensive agriculture, mining and activity from the volcanic regions with the potential for contamination with organic matter and leaching of nutrients in mineral fertilizers such as arsenic, lead, mercury, fluoride, iodide and other toxic metalloids and heavy metals. The microbiological pollution observed is a result of domestic wastes and debris carried by storm water into the natural water bodies (MININFRA, ESMF Report 2011, 2014, 2015).

Muvumba is a river in northeastern Rwanda and southwestern Uganda. It is part of the upper headwaters of the Nile. At $170 \mathrm{~km}$ long, it is one of the major rivers of Rwanda. Its upper course provides water for tea plantations in the high altitudes of north Rwanda and southwestern Uganda. Its lower course provides water for the dry areas of Nyagatare, facilitating irrigation of rice fields and other crops as well as water for cattle. The river takes its source at Rukomo in Gicumbi district close to the town of Byumba in the high mountains of northern Rwanda. At the source, it is called Mulindi river. This stream is very important to the economy as its valley and the valleys of its tributaries are fertile and contain tea plantations and tea factory. The Mulindi flows north for $28 \mathrm{~km}$ and then enters Uganda where it changes name to Rwabakazi River. Rwabakazi continues northward, then upon reaching the city of Kabale the river changes its course and flows in southeast direction towards Rwanda. This section of the river in Uganda is $55 \mathrm{~km}$ long. The river reenters Rwanda in Nyagatare District and takes the name Muvumba river. It then flows in the northeastern direction for $87 \mathrm{~km}$ and empties into the Kagera river at Kagitumba, the tri-point between Rwanda, Uganda and Tanzania. For the last $30 \mathrm{~km}$ of its course, the river forms the border between Rwanda and Uganda.

The upper course of river Rwabakazi in the mountains of the Northern Province in Rwanda and Kabale district in Uganda has narrow valleys, provides water to many canals that serve to irrigate the plantations. As a result, the river is partially dammed in many locations to control water levels and ensure the availability of water even in the dry seasons. The entire course of river Rwabakazi valley is prone to flash flooding due to the heavy rains that fall in the mountains of its upper reaches. Heavy rains falling on bear laterite soils of the mountainous Kabale region dissolve soil components to cause the waters of river Rwabakazi appear read brown all the time. As a result of flooding waters of river Rwabakazi are bound to be heavily polluted because water runs over farm land carrying nutrients, heavy metal ions and silt to the river. These floods can paralyze the lower course of the river, closing off roads and bridges while damaging crops. Outside of extensive farming, the wild lower reaches of the river support forest with wild game.

Safe, fresh water is indispensable resource for humans, livestock and good public health, whether it is used for drinking, domestic, food production, or to sustain the integrity of agro-ecosystems. Improved water supply and sanitation, and better management of water resources, can increase countries' economic growth and contribute significantly to poverty reduction (Pearson and McPhedran 2008). Worldwide, 884 million people, i.e., $12 \%$ of the global human population, lack fresh drinking-water service within a radius of 30 minute walk, including 159 million people who are entirely dependent on surface water (WHO 2017). Globally, more than 2 billion people use a drinking water that is contaminated with faeces, and readily suffer from diseases like diarrhoea, cholera, dysentery and typhus (WHO 2017).

Despite government measures to improve access to clean water, sanitation, and hygiene (Ministry of Infrastructure 2010), surface water in river valleys is polluted through use of fertilizers and pesticides in agriculture (MINIRENA 2011). Furthermore, settlements and farms are often located along valley slopes where 
water run-off flushes manure, human excreta, and wastewater to rivers and streams, leading to increased levels of dissolved nitrogen thus polluting surface water and deterioration of public health results (Sekomo et al. 2012). Increasing human (NISR 2014) and livestock densities (Wronski et al. 2017) in areas like the Mutara rangelands, made surface water more polluted. River Muvumba/Rwabakazi lies in the Nile River Basin to the East that receives greatest quantity of water in Kabale district and neighboring Rwanda (Sekomo et al. 2012, 2012a), its pollution levels impact directly on lake Victoria and the Nile. In a study characterizing the water quality in the two major affluents to the Kagera River, which represents the main drainage line within the Nile River Basin, using biological water monitoring using the Tanzania River Scoring System (TARISS) (Kaaya et al. 2015) to assess the environmental condition of freshwater bodies (Kasangaki et al, 2006; 2008; Liess et al. 2008) revealed a poorer quality than previously reported (RNRA 2014) showing deteriorated public health, because a large population in the area relied on polluted surface water to sustain livelihood. Agriculture and deforestation caused the high load of suspended materials in increased runoff from fields on the steep-sided slopes, increasing the concentration of fertilizers (Sutherland et al. 2002). Application of fertilizers like phosphate and nitrate increases alkalinity of the river water and adversely affect the macroinvertebrate abundance and diversity. It was reported that surface water traveling through schistose or metamorphous bedrock areas of the Byumba escarpment has low hardness and low pH (Ndayisaba and Mihale 2015).

Quantification heavy metal ions and turbidity in the Kagera river using sample stations on tributaries, Nyabarongo, Akanyaru and Muvumba indicated that the levels of Copper and Lead in Akanyaru are higher than those in other rivers, while Muvumba river shows high concentration of Cadmium of about $0.965 \mathrm{mg} / \mathrm{L}$. thus revealing that the river contains higher heavy metal concentrations than recommended by WHO, this presents serious problems to the aquatic life and to the different water users. The high levels in the river were attributed to agricultural, industrial and high erosion levels in the catchment (Nshimiyimana et al 2010). Determination of selected physicochemical parameters in the Nyabugogo river system revealed that both urbanized and rural sub-catchments have serious but different types of pollution. The water from rural areas was heavily contaminated with nutrients, suspended sediments and organic materials whilst from urban areas contained heavy metals and some nutrients (Nhapi, 2011). Evaluation of physicochemical properties of water and selected heavy metals in muscles of fish Protopterus annectens from Nyabarongo and Nyabugogo rivers selected from Ruliba station and Kirinda bridge on Nyabarongo river and Giticyinyoni on Nyabugogo river showed average temperature, $\mathrm{pH}$, total dissolved solids and electrolytic conductivity of water from the rivers were within WHO acceptable limits (Omara et al, 2020). Studies showed pollution of rivers Nyabarongo and Nyabugogo (Nhapi et al, 2011) that drain to Kagera river and ultimately pour water in Lake Victoria, the life artery of East African countries. The pollution of Lake Victoria due to anthropogenic activities is rated among the top ten worldwide (Grinning.2019) and the increasing load of contaminants has greatly deteriorated the quality of water and fish from this freshwater lake (Ogwok et al 2009). The presence of toxic heavy metals in fish poses health threats such as development of cancer, renal failure, liver damage, cardiovascular diseases and eventually death ( CastroGonz'alez and M'endez-Armenta, 2008; Al-Busaidi et al 2011; Rahman et al. 2012). Heavy metals like manganese, zinc, copper, iron, nickel, lead and cadmium were reported in the edible parts of Colocasia esculenta, Amaranthus spinosus, Ipomoea batata and soils from industrially active parts of Kigali, Rwanda (Etale and Drake, 2019; Hakizimana et al, 2019).

Surface water pollution is envisaged by plastics and garbage floating in lakes, rivers and oceans (Musingizi et al. 2013). Surface water pollution may include industrial accidents like oil spills sewage and wastewater. Ground water pollution happens beneath the soil and is caused by highly toxic chemicals like pesticides or chemical spills. Depletion of oxygen in water is caused by microorganisms present in polluted water that consume biodegradable wastes (Syafalni et al. 2013). The quality of water in the river was shown to be influenced by nutrients loading in runoff from the catchment and population centers upstream (Cózar et al. 2007; Bracchini et al. 2007). Water pollution occurs when harmful substances often chemicals or microorganisms contaminate a stream, river, lake, ocean, aquifer, or other body of water, degrading water quality and rendering it toxic to humans or the environment. Water is vulnerable to pollution because it is universal solvent. Toxic substances from farms, towns, and factories readily dissolve into and mix with it, causing water pollution. As water runs over and through the watershed, it picks and carries contaminants and soil. If untreated, pollutants wash directly to 
water ways. The contaminants may infiltrate the ground water, and concentrate in streams and rivers. Agricultural practices in the hinterland to river Rwabakazi greatly affect the purity of water in the river (Singh et al. 2018). Industries, garbage dumping site and abattoir may generate wastewater containing high concentration of greases or oils, heavy metal ions, volatile organic compounds or nutrients like ammonia and phosphates and should require special treatment before discharge to the catchment areas of the river but this may not be done due to lack of equipments, knowledge and the will to act right. Such treatment may require use of clay to adsorb nutrients and photo-decompose algae (Kennedy et al. 2018). Commercial fertilizers, manure or sludge introduces nutrients in water, but nutrients may also enter a water mass through runoff from crop residues, irrigation water or wildlife. Farms with large livestock and poultry operations may pollute the environment through littering. Water flowing to streams picks dirt along the way and gets polluted and no care has been given.

The development of human settlements on the hills around Kabale involved removing plants, changing surface topography and altering natural water drainage networks. This affected the river Rwabakazi heavily. Manmade land covers like tarmacked roads and buildings act as fast lanes for rain water to the river. Rain water which would be absorbed by soil and plants is sent directly to streams this increased chances of flooding of the river because more water pools form in the area than would reach if nature was still restricting its flow.

It is crucial to understand the common substances in water because they are vital part of life and are commonly used to drink and cleanse. A common method of evaluating water sample is by testing the water hardness. Water is said to be hard when there is a substantial concentration of magnesium and calcium ions (Sen Gupta, 2013).

Elemental iron is rarely found in nature, as the iron ions $\mathrm{Fe}^{2+}$ and $\mathrm{Fe}^{3+}$ readily combine with oxygen and sulfur containing compounds to form oxides, hydroxides, carbonates, and sulfides. Dissolved iron more commonly exists in the form of its oxides. To provide safe drinking water to the public, both government and private organizations measure iron content in drinking water and other tap waters in every sector including schools, hospitals, industries (EPA, 2017). Rivers contain approximately 0.5-1 ppm of iron, and groundwater contains 100 ppm. Drinking water may not contain more than $200 \mathrm{ppb}$ of iron. Dissolved iron is mainly present as aqueous $\mathrm{Fe}(\mathrm{OH})_{2}{ }^{+}$under acidic and neutral, oxygen-rich conditions. Under oxygen-poor conditions it mainly occurs as binary iron. Iron is part of many organic and inorganic chelate complexes that are generally soluble in water. Dissolved electrolytes accelerate the reaction mechanism, which is as follows:

$$
\begin{aligned}
& 4 \mathrm{Fe}+3 \mathrm{O}_{2}+6 \mathrm{H}_{2} \mathrm{O} \longrightarrow 4 \mathrm{Fe}^{3+}+12 \mathrm{OH}^{-} \\
& 4 \mathrm{Fe}^{3+}+12 \mathrm{OH}^{-} \longrightarrow 4 \mathrm{Fe}(\mathrm{OH})_{3} \text { or } 4 \mathrm{FeO}(\mathrm{OH})+4 \mathrm{H}_{2} \mathrm{O}
\end{aligned}
$$

Iron in young children negatively affects mental development, impairs irritability, and causes concentration disorder. Young children, pregnant women and women in their period are often treated with iron (II) salts upon iron deficits. Iron present in water can be used as basis to study pollution.

Turbidity measurements and filtration processes are often used to assess the amount of suspended solids in water. In a study monitoring the total concentration of polycyclic aromatic hydrocarbons (PAHs), the amount of total suspended solids, and turbidity in Germany showed linear correlations of turbidity and TSS. TSS are a major pollutant that affects waterways all over the world. Predicting the values of TSS is of interest to quality control of wastewater processing and time series data for TSS are constructed using influent flow rate and influent carbonaceous bio-chemical oxygen demand (CBOD) (Verma et al., 2013). It is accepted that SS are an extremely important cause of water quality deterioration leading to aesthetic issues, higher costs of water treatment, a decline in the fisheries resource, and serious ecological degradation of aquatic environments and recommended water quality guidelines for concentrations of SS in freshwater systems have been set (Bilotta et al., 2008). 
Turbidity expresses the cloudiness or haziness of polluted water caused by suspended solids that are usually invisible to the naked eye. Turbidity of water may be caused by silt, clay, algae or other organisms present in large numbers. The amount and character of turbidity depends on type of soil over which water flows and the velocity of water. Determination of turbidity of water is very important in assessing the suitability of water used for drinking and industrial purposes.

The turbidity is one of the important physical parameters for water quality, defining the presence of suspended solids in water and causes the muddy or turbid appearance of water body. As turbidity increases, it reduces the clarity of water to transmitted light by causing light to be scattered and adsorbed. Turbidity itself does not always represent a direct risk to public healthy, however it can indicate the presence of pathogenic microorganisms and can be effective indicator of hazardous events through the water supply systems from catchment to point of use (APHA 2003). High turbidity in source waters can harbor micro bio pathogens and consumption of high turbid water may cause a health risk, as excessive turbidity can protect pathogenic microorganisms from effects of disinfectants (Singh et al., 2013). Due to the presence of the ions and the amount of suspended solids described above, the waters of river Rwabakazi is polluted. Water pollution is usually defined as any physical, chemical or biological change in water quality which adversely impacts on living organisms in the environment or which makes a water resource unsuitable for one or more of its beneficial uses (Chapman, 1996).

This study aimed at establishing the extent of pollution of waters of river Rwabakazi in Uganda.

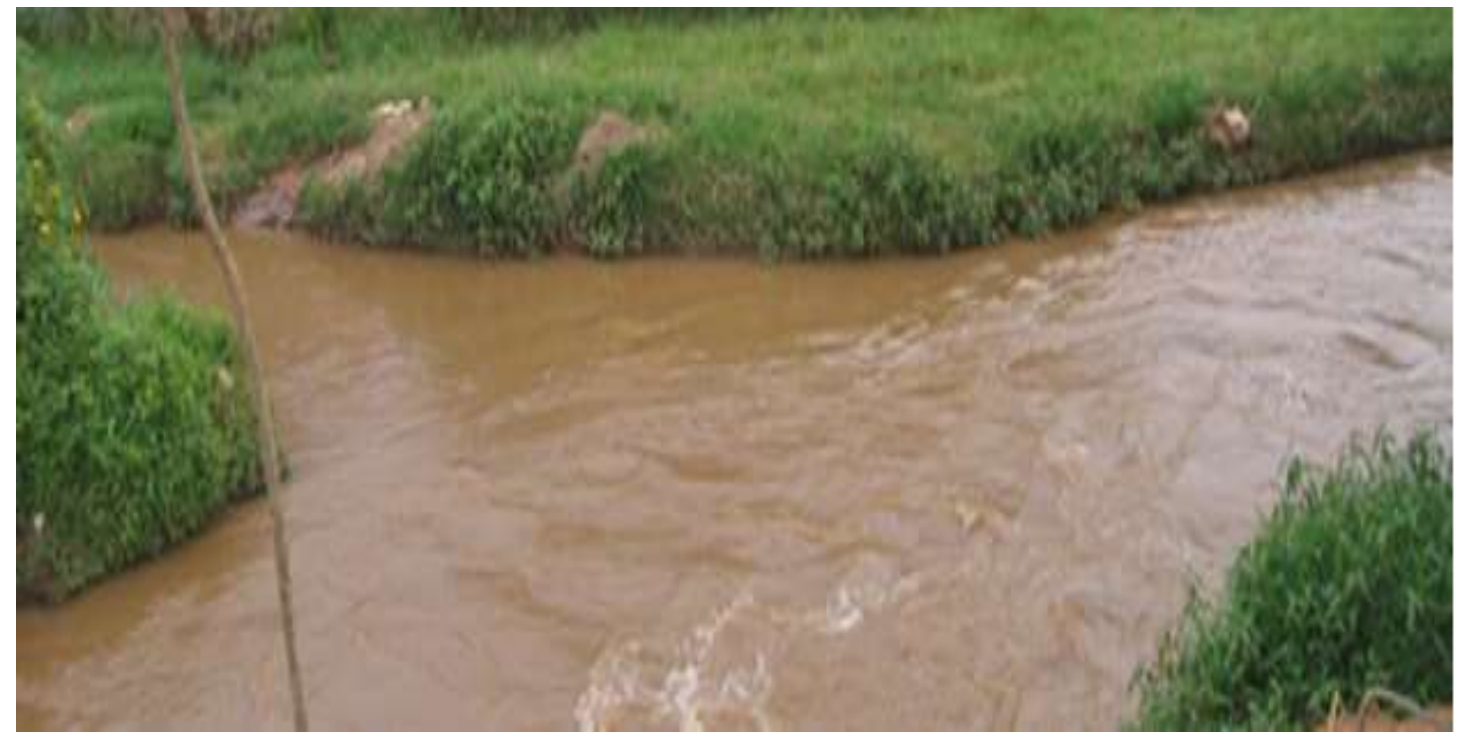

Figure 1: Appearance of water in river Rwabakazi near Kirigime bridge, Kabale town (dark brown color of water flowing)

\section{Materials and Methods}

\section{Description of the Study Area}

River Rwabakazi runs $55 \mathrm{~km}$ in Uganda. It is the major water way draining much of Kabale municipality. Near its banks in Kabale town lies abattoir and garbage landfill near the old market. In the valleys are vegetable gardens where manure, fertilizers and pesticides are used to increase crop yield. Crops like Irish potatoes, sweet potatoes, sorghum, beans, onions and flowers are grown in the valley and the steep slopes. Much of the marshland was reclaimed to hold cattle farms. Many homesteads on the slopes of the Rwabakazi valley either have poor toilet facilities or dump garbage in the valley. There are open surfaces of laterite soils in the area especial where 
stones have been mined. Topography of the overlying hills is changed through grading to pave way for construction of houses, thus increasing speed of surface run

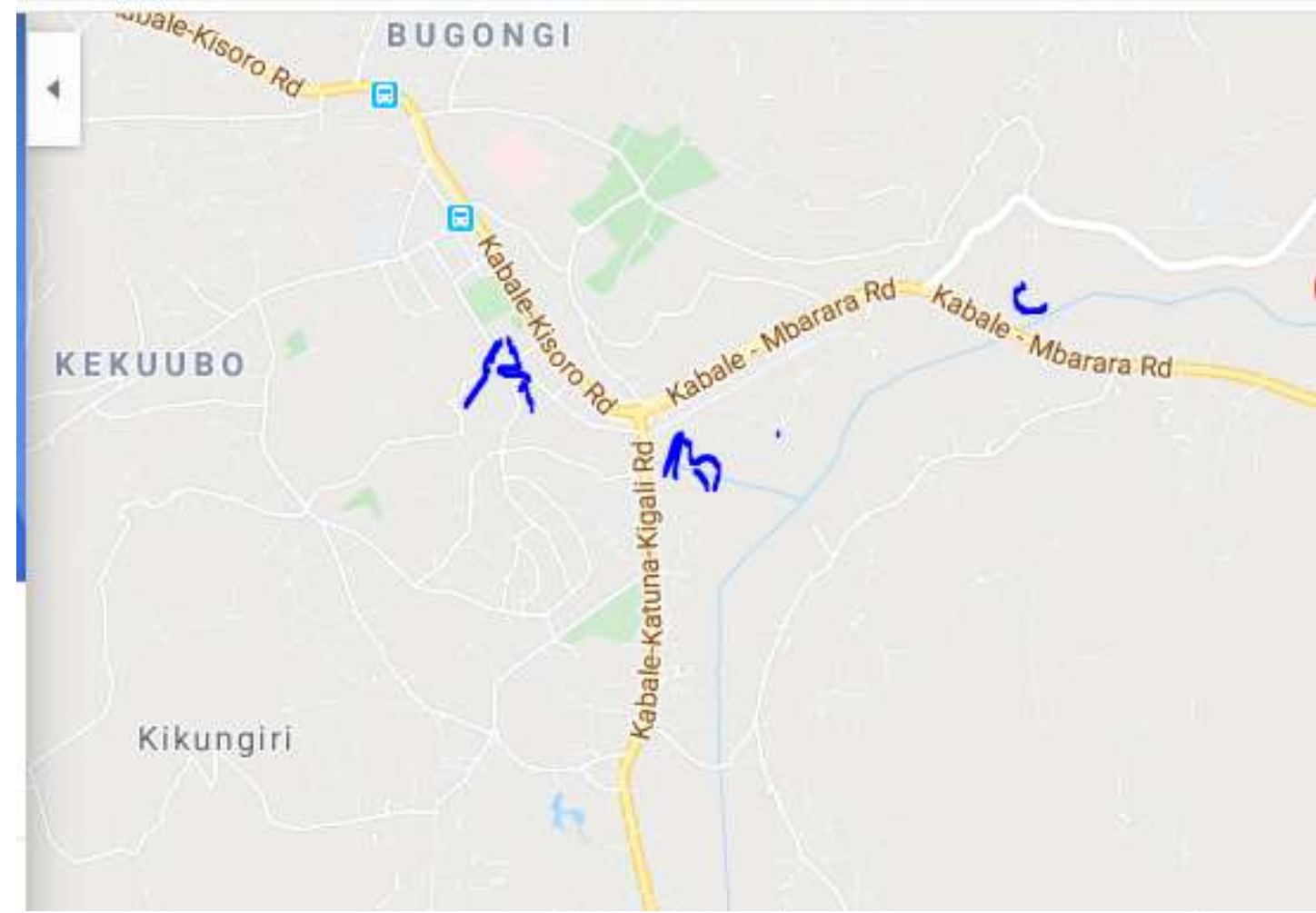

Figure 2. Map of Kabale district showing the location of Rwabakazi river.

Key: $A=$ Kirigime bridge; $B=$ Kabale - Katuna bridge $C=$ Kabale-Mbarara bridge.

\section{Sampling}

Sampling of Water Samples of water (2L) were drawn into plastic bottles, sealed, packed freeze box and transported to the laboratory in Kabale University, where theywere stored in a freezer at $4^{\circ} \mathrm{C}$ for future use. The water used in the study was collected from river bridges at Kirigime, Kabale-Katuna highway and Kabale Mbarara highway at depth of one foot below surface of water. Water was sampled in brown reagent bottles that had been prewashed with nitric acid, detergent and rinsed with distilled water several times. A total of nine samples were collected for analysis. The samples were tightly caped and placed in a cool box immediately. They were then transported to the laboratory, and then filtered using Whatman filter papers to avoid interference due to turbidity and color. Some samples were then kept in a refrigerator at a temperature below $4{ }^{\circ} \mathrm{C}$ while other were allowed to attain room temperature to be analyzed.

The three sampling points were selected in this study after seeing a garbage landfill near Kabale town. So site was chosen near the bridge adjacent to the landfill, site B was chosen to be at another bridge on Kabale Katuna highway $2 \mathrm{kms}$ away from site $A$ and site $C$ was chosen to be at another bridge on Kabale Mbarara highway and in all the river water flows from $A$ through $B$ to $C$ enroute joining Kagera that leads to Lake Victoria. (See Figure 2). This way the variations in metal ions concentrations, suspended solids and other physical parameters of polluted waters would be expected to emerge. Three samples of water were drawn from each site $2 \mathrm{~L}$ each to enable replication of results.

\section{Measuring turbidity of sample}


The sample of water was placed in a tube and shaken vigorously. When gas bubbles disappeared, the sample was transferred to the nephelometer tube. The tube and its contents were inserted in the turbidimeter and turbidity read off.

$$
\text { NTU of sample }=\frac{A(B+C)}{C}
$$

where, $A=N T U$ found in diluted sample; $B=$ volume of dilution water in $m L ; C=$ sample volume taken for dilution in $\mathrm{mL}$

\section{Determination of Iron in water}

The Odyssey spectrophotometer Hach DR 2500 was used.

Part I: Preparation of standard solution

Volumetric flasks were labeled: 0 ppm, 1.0 ppm, 2.0 ppm, 4.0 ppm, $6.0 \mathrm{ppm}$. Using a pipette $0.0 \mathrm{~mL}, 1.0 \mathrm{~mL}, 2.0$ $\mathrm{mL}, 4.0 \mathrm{~mL}$, and $6.0 \mathrm{~mL}$ of the $100 \mathrm{ppm}$ of $\mathrm{Fe}^{2+}$ solution was added to the appropriate flasks. $0.25 \%$ orthophenanthroline solution $(5 \mathrm{ml})$ was added to each flask. Then distilled water was used to make each solution to $100.0 \mathrm{~mL}$ mark. Each of the solutions made was used to record the absorbance.

Part II: Forming the standard curve

The spectrophotometer was warmed up for 20 minutes. The wavelength was adjusted to $510 \mathrm{~nm}$. The cuvette containing the blank $(0 \mathrm{ppm})$ was inserted in spectrophotometer. Then the cuvette containing the sample was put in the sample compartment with the triangle on the cuvette facing the front of the instrument. The lid was closed. The absorbance of water was recorded and the cuvette removed from the instrument. The cuvette containing sample $(1.0 \mathrm{ppm})$ inserted. The lid was closed. Absorbance of sample was recorded. Absorbance for each of the other standard solutions was recorded following similar steps. The data obtained was used to plot calibration curve.

Part III: Preparation and analysis of the unknown

Test sample of water $(5 \mathrm{~mL})$ was put in volumetric flask. $0.25 \%$ ortho-phenanthroline solution $(5 \mathrm{~mL})$ was added to the same flask and mixture made up $100 \mathrm{~mL}$ mark with distilled water. A cuvette was filled with mixture made. The cuvette was placed in the spectrophotometer and absorbance of solution recorded. Absorbance of other test samples were similarly recorded.

\section{Total solid suspended in water determination}

This was performed following standard method 2540. A known volume of vigorously shaken sample (50mL) was filtered into a pre-weighed glass fibre filter disk fitted to suction pump, and washed successively with distilled water. The filter was carefully removed from the filtration apparatus and dried for an hour at $105^{\circ} \mathrm{C}$ in an oven, cooled in desiccator and re-weighed to constant weight.

\section{Determination of calcium}

Water sample $(25.0 \mathrm{~mL})$ was pipetted to clean flask, dilute nitric acid $(5 \mathrm{ml})$ was added followed with dilute sodium hydroxide $(10 \mathrm{~mL})$ and grains of murexide indicator added. The mixture was titrated with standard ethylene diamine tetra acetic acid solution to purplish-violet end point. The titer obtained was recorded and the experiment repeated to obtain consisted results in triplicate. 


\section{Determination of magnesium}

Water sample $(25.0 \mathrm{~mL})$ was pipetted to clean flask, dilute nitric acid $(5 \mathrm{ml})$ was added followed with buffer solution of $\mathrm{pH} 10(10 \mathrm{~mL}), 1 \%$ sodium sulfide solution $(5 \mathrm{~mL})$ and Erio chrome black-T indicator (3 drops) added. The mixture was allowed to stand for one minute and then titrated with standard ethylene diamine tetra acetic acid solution to blue end point. The titre obtained was recorded and the experiment repeated to obtain consisted results in triplicate.

\section{Determination of dissolved oxygen, $\mathrm{DO}_{5}$}

\section{Method 1: Initial DO}

Freshly obtained Rwabakazi water $(25.0 \mathrm{Ml})$ was placed in reaction flask, $2 \mathrm{M}$ sodium hydroxide $(10.0 \mathrm{Ml})$ was added followed with $1 \mathrm{M}$ manganese (II) chloride solution. The flask was stoppered and shaken gently, then $10 \%$ potassium iodide solution $(5.0 \mathrm{ml})$ was added and $1 \mathrm{M} \mathrm{H}_{2} \mathrm{SO}_{4}(10.0 \mathrm{ml})$ and iodine liberated was titrated with standard sodium thiosulfate solution using starch indicator. The titer obtained was recorded. The experiment was repeated to obtain consistent results. The data obtained was used to compute initial DO.

Method 2: DO after five days of incubation in dark at $4{ }^{\circ} \mathrm{C}$.

Samples of Rwabakazi water were stored in fridge at $4{ }^{\circ} \mathrm{C}$ in the dark for five days. Then they were used to perform the experiment outlined in method above in triplicate. The data obtained was used to calculate $\mathrm{DO}_{5}$ as follows;

. $\mathrm{DO}_{5}\left(20^{\circ} \mathrm{C}\right)=[\mathrm{DO}]$ initial $-[\mathrm{DO}]$ final

\section{Determination of pH}

Temperature and $\mathrm{pH}$ were determined on-site using a handheld Jenway $370 \mathrm{pH} / \mathrm{mV} / \mathrm{Temperature}$ meter calibrated using pH 4.0 and 10.0 standard buffer solutions. The electrodes were thoroughly rinsed with distilled water between measurements.

\section{Determination of conductivity}

Conductivity was determined on-site using a calibrated Jenway 4520 Conductivity/TDS meter.

\section{Determination of copper}

The determination of Copper, was performed using Atomic Absorption Spectrophotometer (AAS) set at 372.0 $\mathrm{nm}$ wavelength. The equipment measure absorbance which is proportional to the concentration of each element in the sample over a limited concentration range by use of the Beer-Lambert law.

\section{Results and Discussion}

\section{Characterization of river Rwabakazi waters}

The parameters used to assert whether a water resource is safe or polluted include chemical oxygen demand $(C O D)$, dissolved oxygen $\left(\mathrm{DO}_{5}\right)$, electrical conductivity $(\mathrm{EC}), \mathrm{pH}$, turbidity, concentrations of iron (II), calcium, copper(II) and magnesium ions, total suspended solids (TSS), nutrient concentration and others. Of these parameters, Rwabakazi waters sampled on $14^{\text {th }}$ February, 2020 showed $\mathrm{DO}_{5}$ ranging from to 86 to $96 \mathrm{mgL}^{-1}$, turbidity 305 to $370 \mathrm{NTU}, \mathrm{pH}$ ranging from 7.6 to 7.8 ; iron (II) concentration ranging from 291 to $320 \mathrm{mgL}^{-1}$; calcium ranged from 16.5 to $18.6 \mathrm{mgL}^{-1}$, copper (II) ranged from 0.3 to $0.5 \mathrm{mg} / \mathrm{L}$; magnesium ranged from 13.2 to $16.4 \mathrm{mg} / \mathrm{L}$ yet TSS ranged from 300 to $330 \mathrm{mgL}^{-1}$ in a stretch from Kirigime bridge to bridge on Kabale-Mbarara 
highway, a distance of $8 \mathrm{~km}$. This revealed the impurities were dispersing as we moved down stream along the river valley. The permissible parameters of safe fresh water sources were published to be as follows; $\mathrm{DO}_{5} 68.0$ $\mathrm{mgl}^{-1}$, turbidity is $5 \mathrm{NTU}, \mathrm{pH}$ range of $5-9$, calcium $0.1 \mathrm{mg} / \mathrm{L}$, copper (II) is $0.1 \mathrm{mg} . / \mathrm{L}$, magnesium is $0.1 \mathrm{mg} / \mathrm{L}$, electrical conductivity is $10 \mu \mathrm{S} / \mathrm{cm}$ and iron (II) concentration of $2.0 \mathrm{mgL}^{-1}$ (EPA). Basing published parameters of water, the Rwabakazi waters can be declared heavily polluted.

\section{Variation of $\mathrm{pH}$}

$\mathrm{pH}$ is a very important parameter in water quality assessment because it determines the directions of many biological and chemical processes in a water body. The $\mathrm{pH}$ of water sampled from river Rwabakazi was higher than 7 , the neutral $\mathrm{pH}$ indicating that the water contained basic contaminants. Although the $\mathrm{pH}$ of the water was within the acceptable range for the environmental protection agency(EPA) the alkalinity of polluted water results from presence of hydroxides and hydrogen carbonates of ammonia, calcium or/and magnesium. Decomposing living organic matter from plants and animals including fertilizers may release such ions that increase alkalinity of water. Determination of $\mathrm{pH}$ of water is important in relaying information on presence of inorganic and organic pollutants from water (Inglezakis et al. 2007).

The $\mathrm{pH}$ of water from river Rwabakazi decreased with distance downstream the river; as shown in Fig. 3.

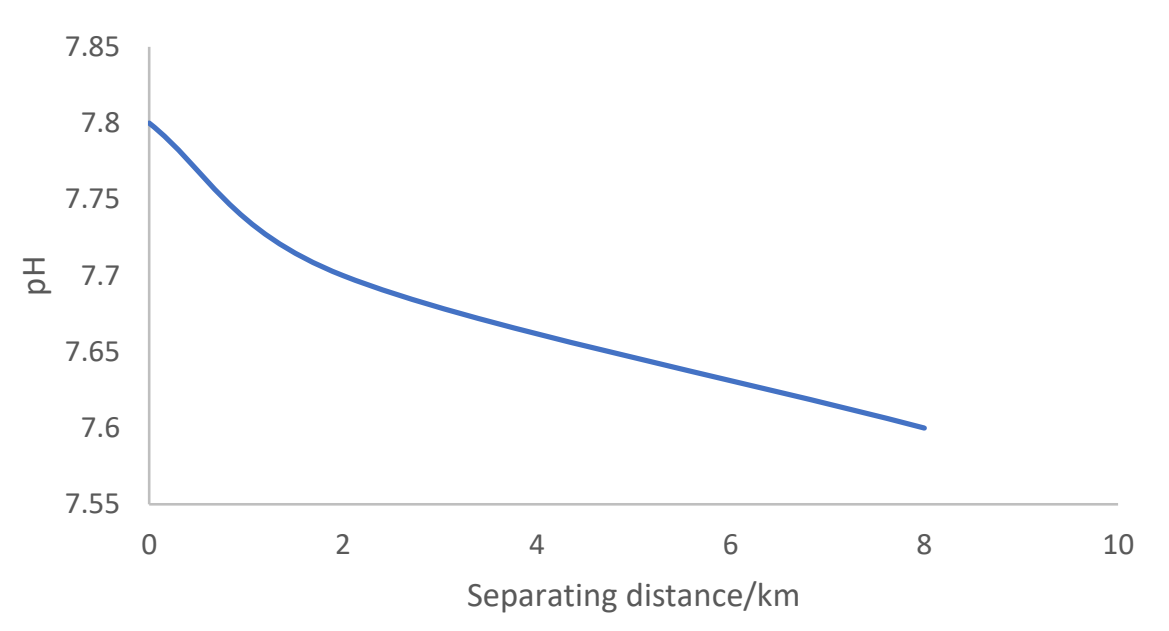

Figure 3: Variation of mean $\mathrm{pH}$ of Rwabakazi water with distance between sampling sites

The mean $\mathrm{pH}$ of water decreased as shown above because the polluted waters formed colloids of different substances in addition to mixing with minerals like clays at the bed of the river valley. Such interactions resulted in formation of heavier colloids that eventually settled along the way thereby removing ions that raise $\mathrm{pH}$. It is not surprising that the color of water also changes from dark brown to lighter tones as water flows a sign showing removal of some ions naturally.

\section{Variation of iron}

The concentration of iron in drinking water should not exceed $0.30 \mathrm{mg} / \mathrm{liter}$. Since the daily nutritional requirement of iron is 1 to $2 \mathrm{mg}$, this standard is for aesthetic reasons rather than toxicity. However, iron concentrations of above $1.0 \mathrm{mg} /$ liter are detrimental to many freshwater fish (EPA). The level of heavy metal pollution of a water resource can be traced through quantifying iron. In this study the mean concentration of iron varied from as high as 380 to as low as $290 \mathrm{mgl}^{-1}$ in Rwabakazi waters. These very high values implied that 


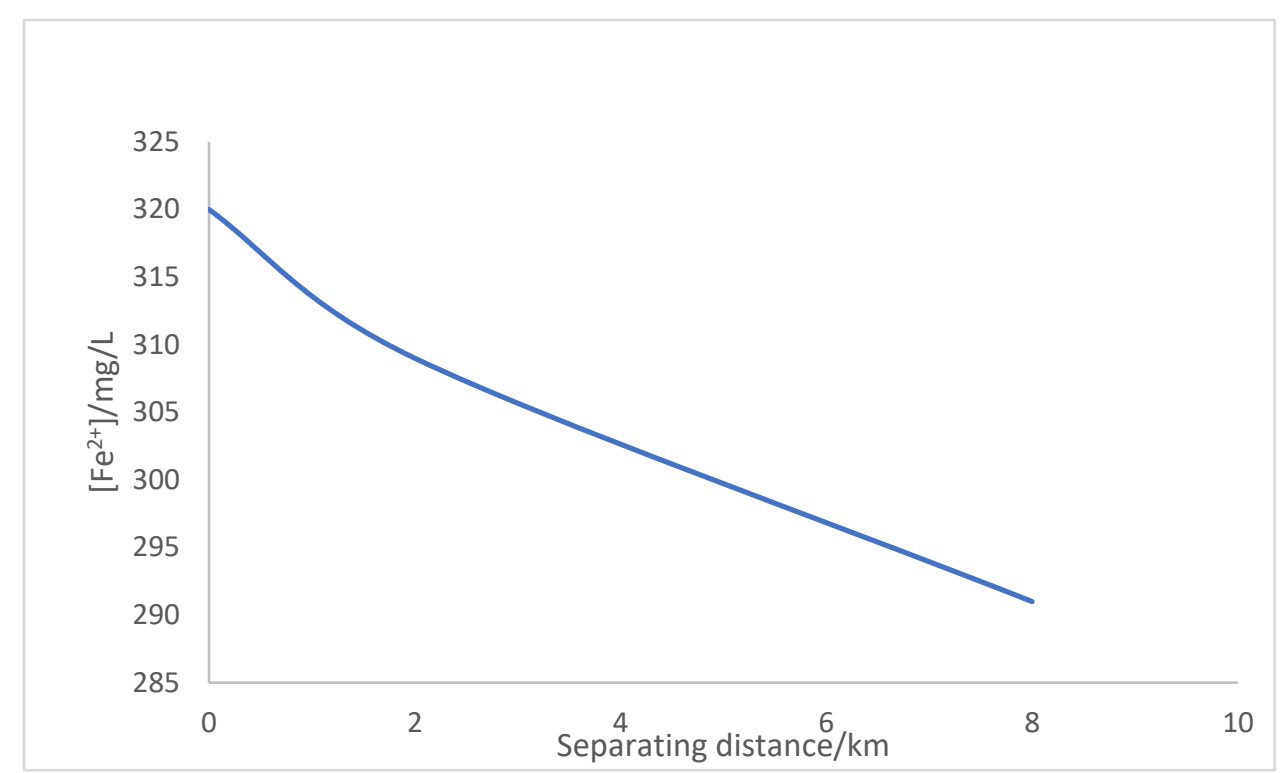

the river is highly polluted because the allowed limit is $2.0 \mathrm{mgl}^{-1}$ (EPA) and the recommended that the concentration of iron in drinking water should not exceed $0.30 \mathrm{mg} /$ liter (EPA, APHA, 2003). The high levels of heavy metal contamination of Rwabakazi water results from strong soil erosion of laterite soils upstream and anthropogenic activities in the hinterland to the selected sample sites. River Rwabakazi flows from northern Rwanda in an area of heavy agricultural and industrial activities. Poor management agricultural, domestic or/and factory waste can cause pollution. Similarly, flash floods common to this mountainous region that receives much rain can increase surface water pollution. So concentrations of heavy metal ions rise drastically.

The mean concentration of iron in Rwabakazi waters decreased as distance increased downstream the river as shown in Fig. 4. The decrease in mean concentration of iron downstream revealed that when polluted waters travel long distances when in contact with rocks and soil reactions take place resulting in depollution.

Figure 4: Variation of mean $\left[\mathrm{Fe}^{2+}\right]$ in Rwabakazi water with distance between sampling sites

Reactions that lead to formation of colloids must be responsible for the depollution because of the double charge layer nature of colloids and diminution in stability of the colloids when changes occur as the water flows over the clays and other rock bed minerals found in the basement of the river valleys. Electric neutralization of colloidal suspensions in water results in deposition of the colloid and reliving pollution.

\section{Variation of mean concentration of calcium}

Calcium is present in all waters as $\mathrm{Ca}^{2+}$ and is readily dissolved from rocks rich in calcium minerals, particularly as carbonates and sulphates, especially limestone and gypsum.

Calcium and magnesium ions present in a water resource cause hardness, wasting soap and energy. The mean concentration of calcium in Rwabakazi water was high and ranged from as high as $18.9 \mathrm{mg} / \mathrm{L}$ to $16.5 \mathrm{mg} / \mathrm{L}$ showing that the water is very hard. Rwabakazi waters derives its hardness from the agricultural in puts, like NPK fertilizers, limestone rocks, plant and animal debris rotting in water upstream (Sekomo et al 2012). The Rwabakazi valley is an area of heavy agriculture because of presence of fertile soils and abundant water. However, as shown in Fig. 5, the mean concentration of calcium in water decreased with increase in distance downstream, so a fall in hardness of water was observed. 


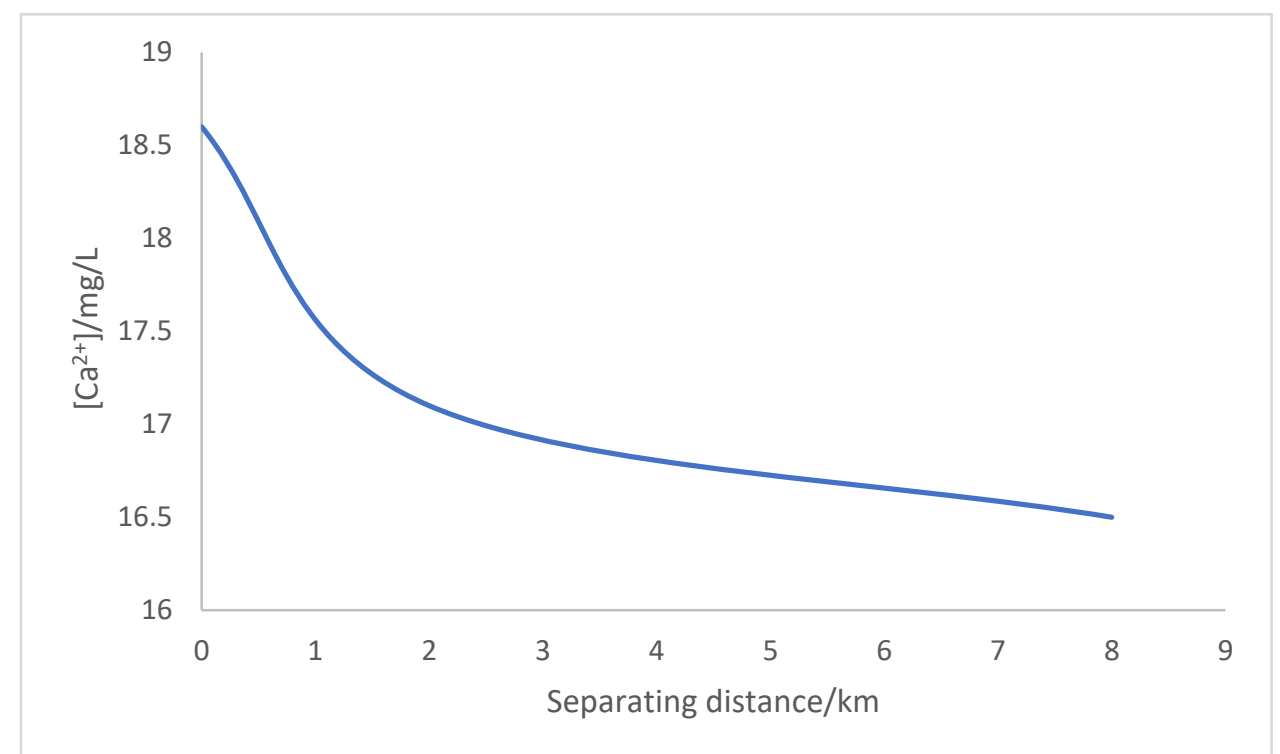

Figure 5: Variation of mean $\left[\mathrm{Ca}^{2+}\right]$ in Rwabakazi water with distance between sampling sites

Deposition of calcium salts on the bed of the river, thereby reliving hardness.

\section{Variation of concentration of magnesium}

The mean concentration of magnesium in Rwabakazi water varied from 16.5 to $14.5 \mathrm{mg} / \mathrm{L}$ in sampled water. The concentrations are higher than the allowed limits of $0.1 \mathrm{mg} / \mathrm{L}$ (APHA 1995) and indicate the water is extremely hard. The extreme hardness may have resulted from water flowing over mineral beds containing soluble magnesium salts, agricultural lands and decomposing plants (Potasznik and Szymezyk, 2015; Grochwrorsk and Tondyrak, 2009).

The mean concentration of magnesium decreased downstream as shown in Fig. 6 below due to reactions which favored precipitation of calcium ions from Rwabakazi waters.

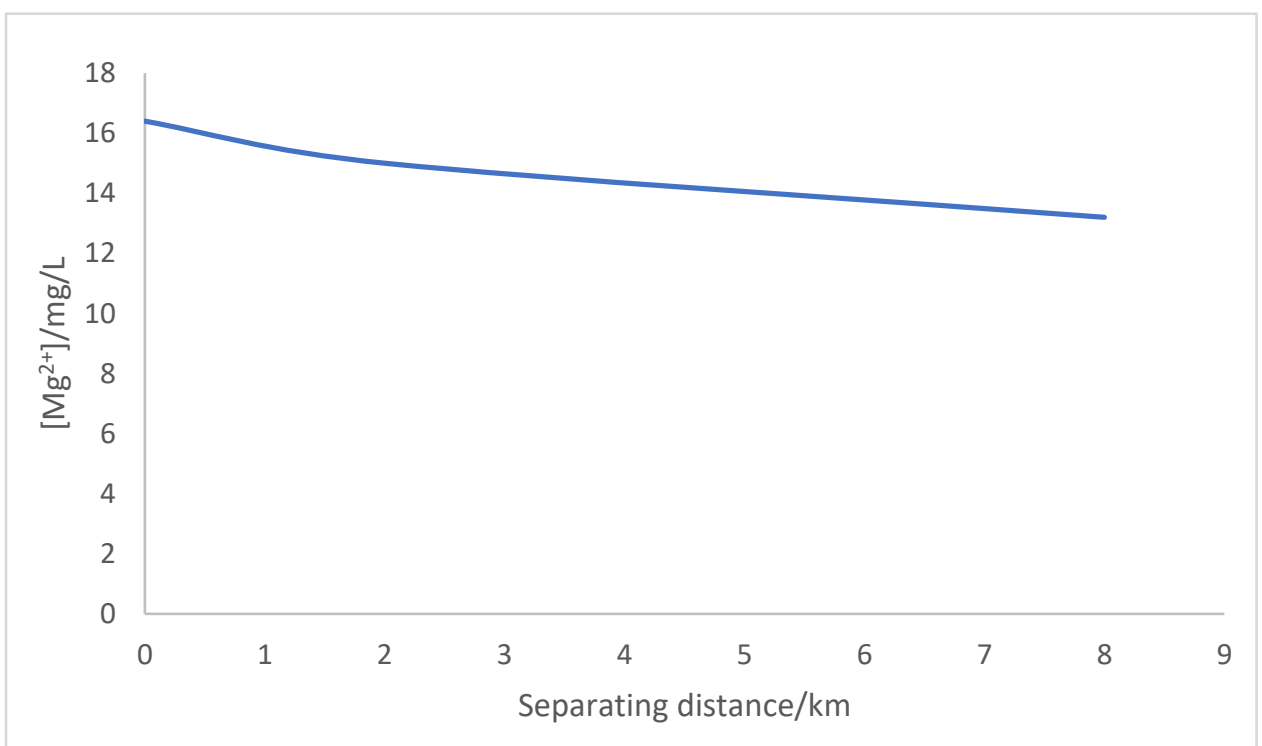

Figure 6: Variation of mean $\left[\mathrm{Mg}^{2+}\right]$ in Rwabakazi water with distance between sampling sites 
The decrease in magnesium concentration downstream Rwabakazi river indicates that salts in the water diminish as the water runs over the river bed containing clay and other minerals that readily flocculate magnesium ions in polluted water and cause the deposition on the river bed.

\section{Variation of Copper}

The mean concentration of copper (II) ions in Rwabakazi water varied from as high as $0.5 \mathrm{mg} / \mathrm{L}$ to as low as 0.3 $\mathrm{mg} / \mathrm{L}$. These values are higher than permitted values in useable freshwater of $0.1 \mathrm{mg} / \mathrm{L}$ (UNEP, 2008).

The mean concentration of copper decreased downstream as shown in Fig. 7 below. The fall in concentration of copper in Rwabakazi water must have resulted from the high $\mathrm{pH}$ of the polluted water. Copper (II) hydroxide and carbonate readily precipitated to the bedrock of the river to relieve pollution effects.

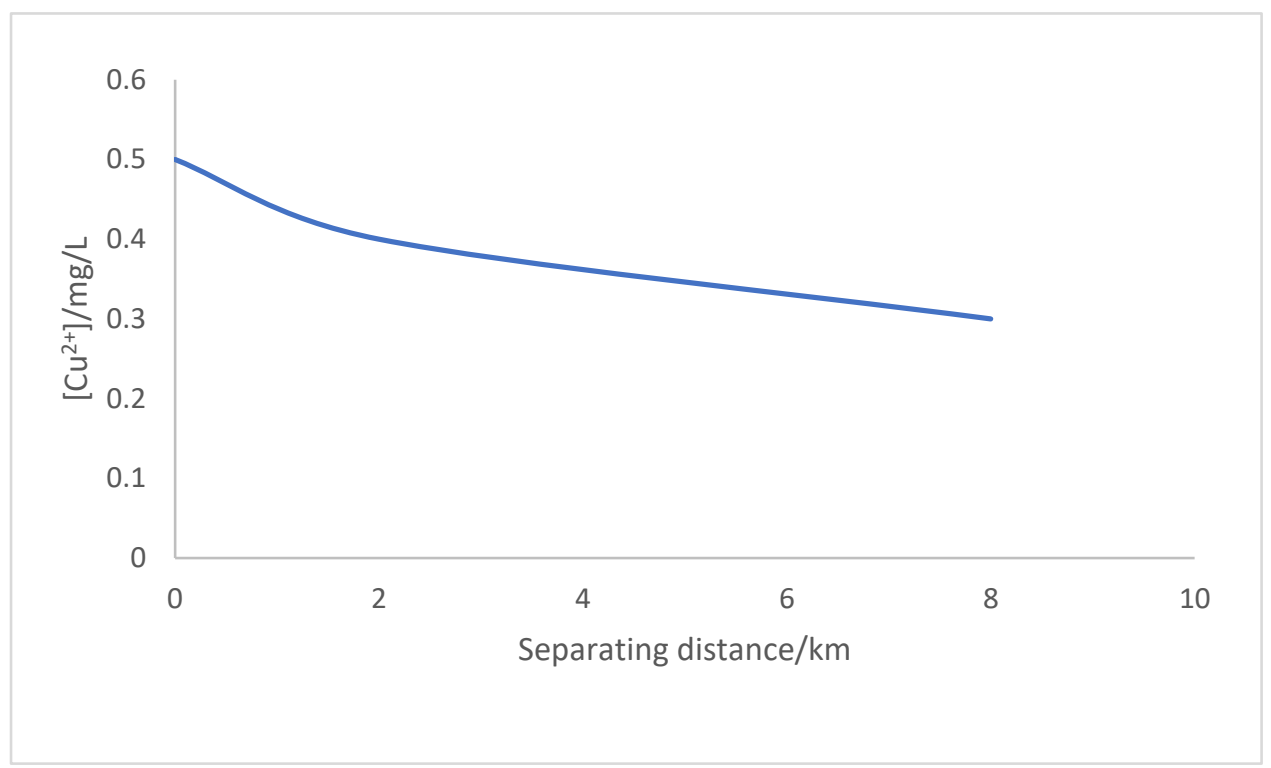

Figure 7: Variation of mean $\left[\mathrm{Cu}^{2+}\right]$ in Rwabakazi water with distance between sampling sites

The data obtained is agreement with work done elsewhere on rivers in this region (Nshimiyimana et al., 2010).

\section{Variation of mean concentration of dissolved oxygen}

These higher values of oxygen when compared to the standard limit is good for the maintenance of aquatic life and the self-purification process of these natural water bodies. Normally oxygen is essential to all forms of aquatic life, including those organisms responsible for the self-purification processes in natural waters. The oxygen content of natural waters varies with temperature, salinity, turbulence, the photosynthetic activity of algae and plants, and atmospheric pressure. Oxygen is required for aerobiosis, influences inorganic chemical reactions, affects parameters of water like taste, degree of asepsis and consumed by decomposition of organic matters (Chapman, 1996). The amount of dissolved oxygen in water is inversely proportional to the temperature of the water (UNEP, 2006). The oxygen content of natural waters varies with temperature, salinity, turbulence, the photosynthetic activity of algae and plants, and atmospheric pressure. The mean concentration of dissolved oxygen in Rwabakazi water ranged from as high as $96 \mathrm{mg} / \mathrm{L}$ to as low as $86 \mathrm{mg} / \mathrm{L}$. The permissible lower limits of dissolved oxygen is $68 \mathrm{mg} / \mathrm{L}$ (EPA). This high quantity of dissolved oxygen showed that Rwabakazi waters can support life and the river has capacity to clean itself naturally.

The mean concentration of dissolved oxygen decreased as distance increased down Rwabakazi river as shown in Fig. 8. 


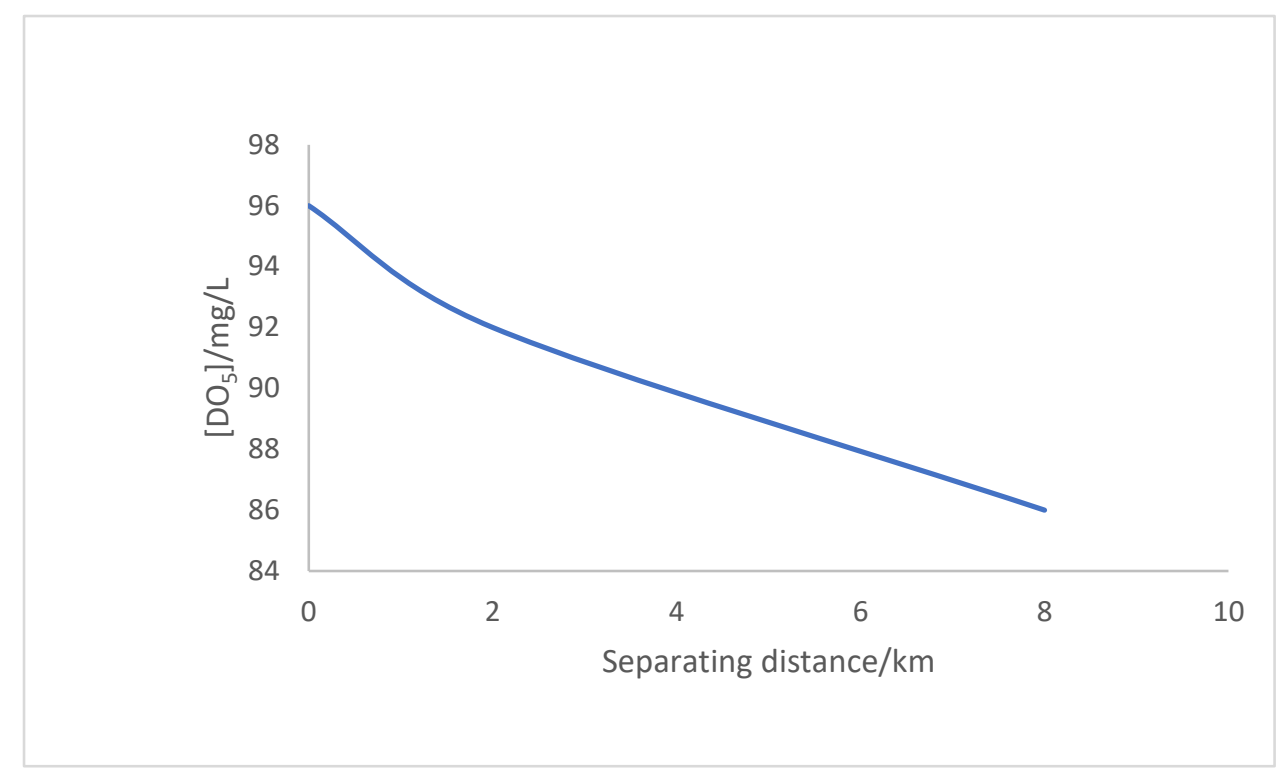

Figure 8: Variation of mean $\left[\mathrm{DO}_{5}\right]$ in Rwabakazi water with distance between sampling sites

Dissolved Oxygen in waters depends on temperature of water, partial pressure of atmospheric oxygen and quantity of salts in waters, physicochemical and biological activity in water body. Salinity decreases dissolved oxygen concentrations. The dissolved oxygen level for Rwabakazi water is higher than $5 \mathrm{mg} / \mathrm{L}$ indicating life processes go on well and the water carries out self-purification. The decrease in concentration of dissolved oxygen with distance downstream may be a result of increasing salinity of water. These higher values of oxygen when compared to the standard limit is good for maintenance of aquatic life and natural purification process of the river.

\section{Variations in TSS}

Matter suspended in surface water consists of silt, clay, fine particles of organic and inorganic matter, soluble organic compounds, plankton and other microscopic organisms and these reflect the total suspended solids. Measurements of TSS in surface water are useful in estimating quantity of solid sediments transported in water because they have significant effects downstream where the water is received. TSS can be used to explain the season of sampling, occurrence of soil erosion and surface run off. TSS is large in rain season because soil erosion occurs and the surface runoff is high. High TSS is harmful to fish. The total amount solids suspended in waters of Rwabakazi ranged from 330 to $300 \mathrm{mg} / \mathrm{L}$. The TSS for the river is too high as compared to the permissible limit in surface fresh water is $30 \mathrm{mg} / \mathrm{L}$ (EPA). The very high TSS in Rwabakazi water must have resulted from the heavy rain water eroding much of the laterite soils upstream. Exposed laterite soils up the surrounding mountains and ridges in the south of Kabale district are numerous, coupled to the heavy rains that fall in the mountains, soil erosion is rampant. Silt and top soil is carried to the Rwabakazi valleys by the fast moving storm waters. This increased the TSS of water sampled.

Presence of such a large mass of suspended solids in water is indicative of contamination by soluble and insoluble materials in water carried from the streams feeding Rwabakazi river, from laterite soils devoid of plant cover made open by human and livestock explosions in the hinterland to the Rwabakazi valleys. Thus why the water appears dark brown in color. High TSS indicates that as more human habitats were created in the Kabale and the surrounding mountains in Rwanda, more drainage canals were constructed and the volume of water that runs very fast to Rwabakazi valleys is larger than ever. More suspended solids reach river than ever before leading due to flooding in areas of the mountains receiving heavy frequent rains with massive soil erosion. So higher rate of pollution in the Rwabakazi river could be due to the ongoing wetland encroachment for agricultural purposes and rapid increase in the pollutant loading in the streams flowing to the Rwabakazi valley. Consequently, the TSS becomes high large. High TSS also indicates the rapid rate of flow of surface water runoff in this highly mountainous area and also the loose nature of the laterite soils in the area. 
The variations in mean concentrations of TSS with distance between sites where the study samples were picked is shown in Fig. 9 below. As shown on Fig. 9, the mean concentration of TSS decreased downstream probably due to collapse of colloids in mixture flowing resulting from neutralization of electrostatic charges which resulted in massive settling of suspended solids on the rock bed over which the river flows.

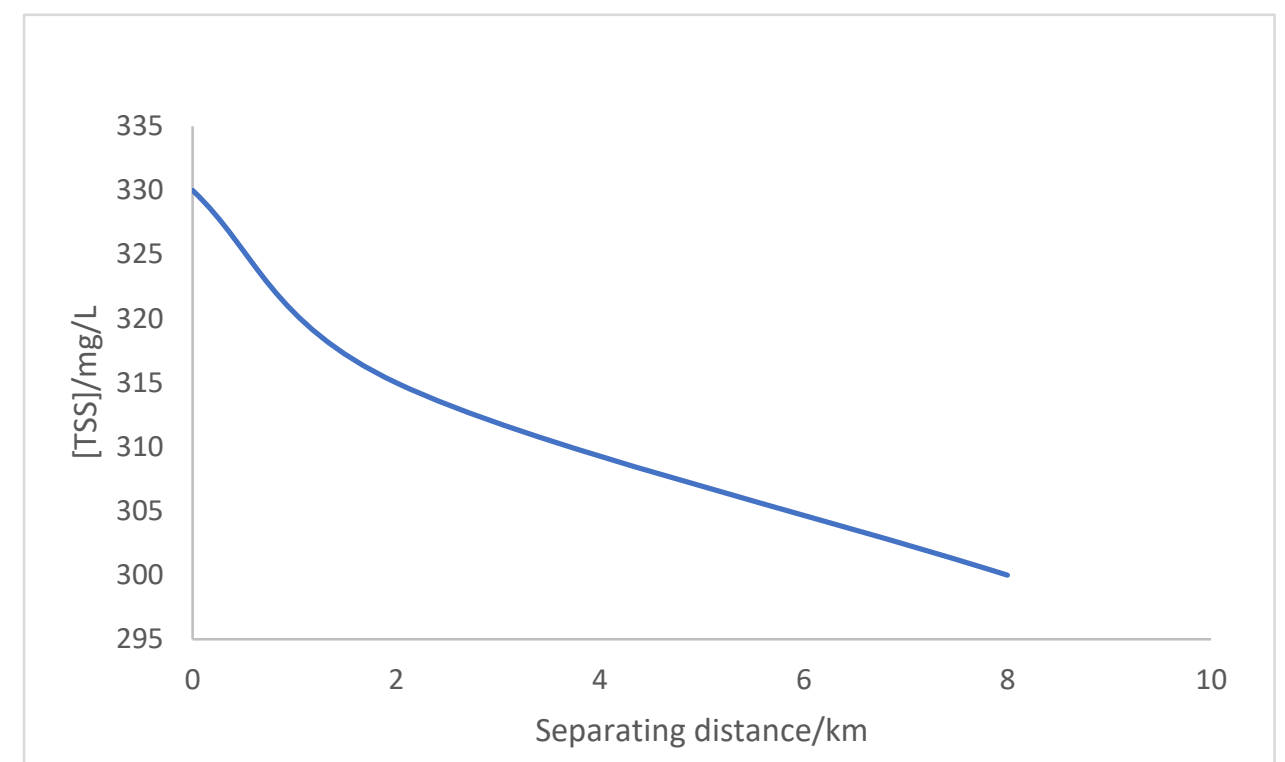

Figure 9: Variation of mean [TSS] in Rwabakazi water with distance between sampling sites

The very high TSS values obtained in this study may reveal that fish do not readily survive in Rwabakazi waters. Total suspended solids commonly result from sediments carried by the water and the source of sediments can be natural and anthropogenic activities in the watershed, such as excessive soil erosion from agriculture, forestry, mining or construction.

The behavior of water running in the Rwabakazi valley resembles colloids suspended in water. Colloids could remain in suspension due to a number of processes. The deposition of the particles in Rwabakazi water may have occurred through processes like surface filtration, size exclusion, bridging, and attachment. (McDowellBoyer et al. 1986). It was also possible that suspended solids were removed through hydrodynamic bridging. Bridging may have occurred when several suspended particles wedged together (de Zwart, 2007). A bridge consisting of multiple particles may have formed and thereby excluding dissolved and suspended solids from Rwabakazi water to diminish TSS. Particle bridging occurred under the influence of speedy rotation when Rwabakazi water is flowing through the valley. Speedy rotation of suspended solid particles increases the probability that several particles collide at same surface at the same time (Ramachandran and Fogler, 1999). This is related to force balance between hydrodynamic forces and the repulsive particle-grain forces. At higher flow rates the hydrodynamic forces overcame the repulsive forces, thereby favoring bridging. Suspended solid deposition due to bridging was reported to depend on pore size distribution of the aquifer, the colloid size and concentration, and colloid- grain surface interaction forces (Ramachandran and Fogler, 1999). Thus TSS decreased as distance increased. Another aspect affecting bridging is the colloid concentration suspended in surface water. Higher concentration of TSS increases the colloid flux and therefore leads to an increase of the likelihood of bridge formation (Sen and Khilar, 2006). Since the most important parameters for colloid bridging are particle concentration and flow velocity the high TSS concentrations of Rwabakazi waters would overcome the repulsive particle-grain surface forces which would resist bridging to lead to bridging as the water flowed. Furthermore, small ratios are favorable for bridging, and properties of the colloid like shape, surface charge and roughness (Sen and Khilar, 2006). The complex interplay between multi-body surface interactions and hydrodynamics at nanometric scale leads to coagulation and flocculation may occur in flowing polluted surface water (Bacchin et al. 2011).

\section{Variations in electrical conductivity}


Electrical conductivity capability of water to conduct electric current. It normally reflects variations in dissolved electrolytes, commonly mineral salts. The degree to which electrolytes dissociate into ions, the amount of electrical charge on each ion, ion mobility and the temperature of the solution influence on conductivity measured. The conductivity of freshwaters ranges from 10 to $1000 \mu \mathrm{S} / \mathrm{cm}$ and can exceed $1000 \mu \mathrm{S} / \mathrm{cm}$ for heavily polluted waters. Conductivity measurements can be used to estimate mineral content as well as establishing pollution zones. The electrical conductivity of waters sampled from Rwabakazi river ranged from as high as 150 $\mu \mathrm{S} / \mathrm{cm}$ to as low as $131 \mu \mathrm{S} / \mathrm{cm}$ in the river. The values are higher than recommended values for surface water (EPA) and indicate that the water resource is highly polluted with mineral salts. The values further indicate presence of soluble minerals in the rocks over which water flows. The variation of electrical conductivity of Rwabakazi water with distance between sampled sites is shown in Fig. 10 below. As seen in the diagram electrical conductivity of water decreased downstream indicating deposition of electrolytes to the bed of the river as water flowed downstream.

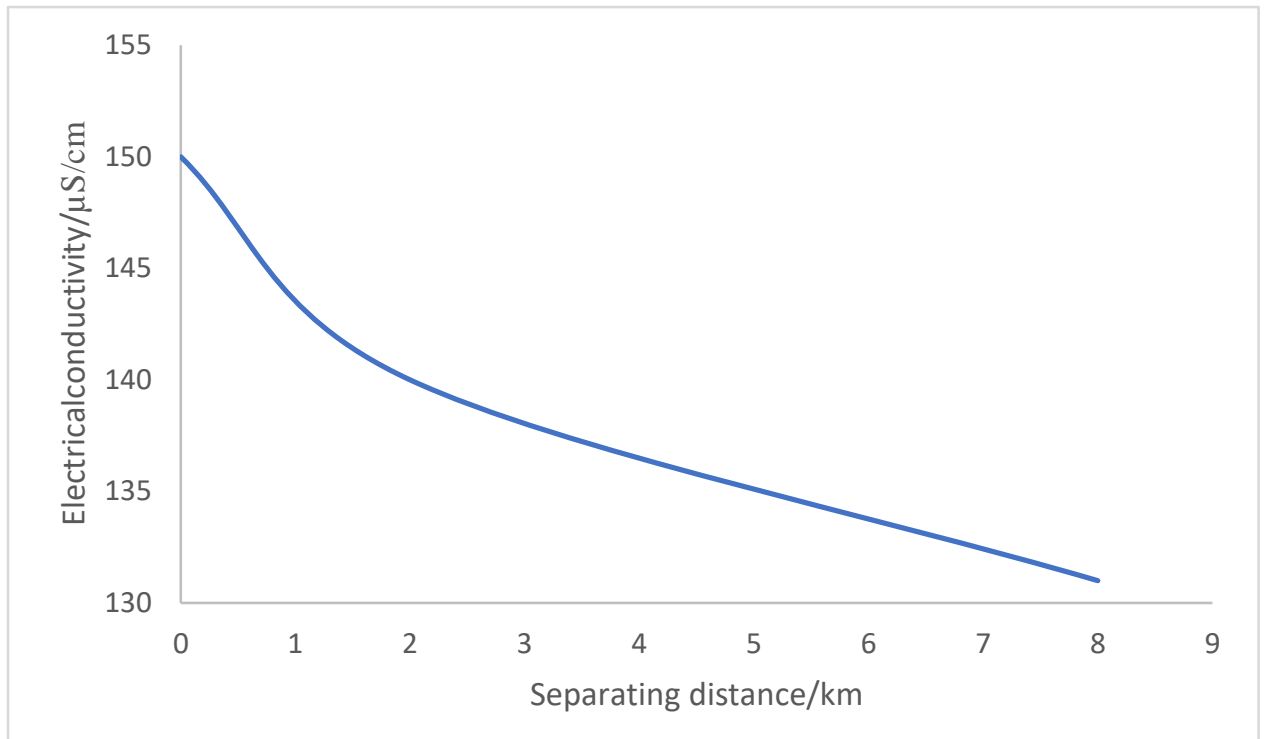

Figure 10: Variation of mean electrical conductivity $(\mathrm{EC})$ of Rwabakazi water with distance between sampling sites

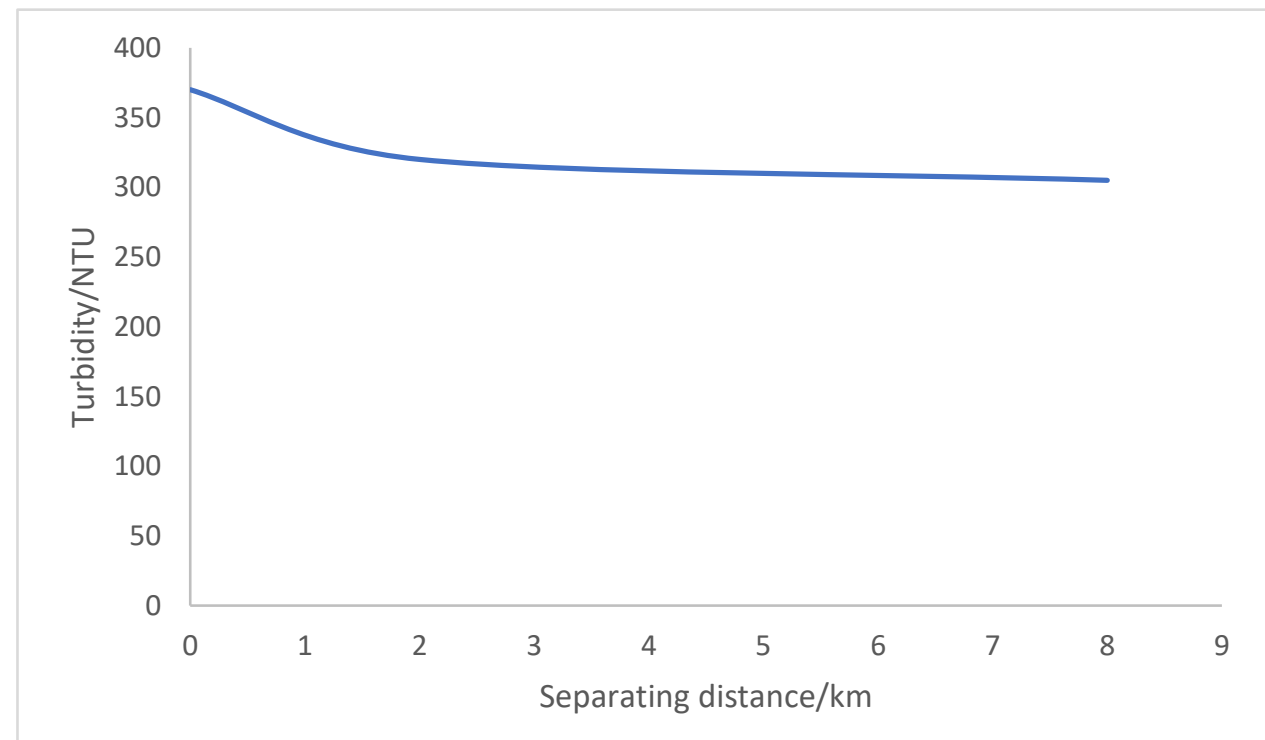

Figure 11: Variation of mean turbidity of Rwabakazi water with the distance between sampling sites 
This can be explained by precipitation of insoluble salts from the water whose solubility constants would be exceeded easily.

\section{Variation in turbidity of Rwabakazi water}

Turbidity measurements result from the scattering and absorption of incident light by the particles in water. They vary seasonally according to biological activity in the water column and surface run-off carrying soil particles. Heavy rainfall results in timely variations in turbidity of a water body. The mean turbidity of water from Rwabakzi river was quite high and varied from as high as 380 NTU to as low as 305 NTU; and these values are higher than permissible for safe surface water (EPA).

The variation of turbidity of water with separating distance between the places from which the water sampled is shown in Fig. 11 below. As observed from Fig. 11, the turbidity of water decreased downstream due to change in composition of the water.

Since turbidity reflect the haziness of the water sampled, fall in turbidity as water moved downstream indicated improvement in the quality of water as it moved through the natural aquifer. This could have resulted from simple dilution or and neutralization of charges on the impurities in the water leading to massive settling of solids from the water to rock bed of the river.

\section{Conclusions}

Rwabakazi waters are highly polluted basing on metal and TSS concentrations determined in this study. The concentrations of metal ions and TSS decreased downstream Rwabakazi river favoring natural cleaning processes of the water body. The concentrations of metal ions and TSS remained very high within the area of study indicating the water remained strongly polluted. Concentrations varied as follows; copper (II) was $0.3 \pm .0 .03 \mathrm{mg} / \mathrm{L}$ to $0.5 \pm 0.03 \mathrm{mg} / \mathrm{L}$; calcium was $16.5 \pm 0.2 \mathrm{mg} / \mathrm{L}$ to $18.6 \pm 0.3 \mathrm{mg} / \mathrm{L}$ iron was $291 \pm 0.2 \mathrm{mg} / \mathrm{L}$ to 320 $\pm 0.3 \mathrm{mg} / \mathrm{L} ;$ magnesium was $13.2 \pm$ to $16.4 \pm \mathrm{mg} / \mathrm{L}$; TSS was $300 \pm 5 \mathrm{mg} / \mathrm{L}$ to $330 \pm 5 \mathrm{mg} / \mathrm{L}$ indicating the aquatic life is at risk of extinction. $\mathrm{pH}$ fell from $7.8 \pm 0.03$ to $7.6 \pm 0.04$ showing removal of basic components. The turbidity dropped from $370 \pm 3$ NTU to $305 \pm 2$ NTU due settling down of sediments. Dissolved oxygen was high and ranged from $86 \pm$ to $96 \pm \mathrm{mg} / \mathrm{L}$ showing life processes take place easily in these polluted waters. Conductivity was high and ranged from $130 \pm 5$ to $150 \pm 5 \mu \mathrm{S} / \mathrm{cm}$ indicating presence of electrolytes.

\section{Recommendations}

The water of Rwabakazi river should be dammed to allow sediments to settle. The management of the river should be directed towards the reduction of nutrient input and reduction of sediment loading.

Sustainable farming methods should be encouraged to avoid an influx of nutrients into the water bodies and impact on the quality of domestic water systems.

Trees with long, strong roots are planted on the bear faces of laterite soil to reduce soil erosion, which ruins color and quality of water.

\section{Acknowledgment}

We are greatly indebted to Mr. Ruhara R. Budigi for the instruments used in analyzing the water.

\section{References}

Al-Busaidi M, Yesudhason P, Al-Mughairi S, Al-Rahbi WA, Al-Harthy KS, Al-Mazrooei NA. (2011) Toxic metals in commercial marine fish in Oman with reference to national and international standards. Chemosphere $85: 67-$ 73. 
American Public Health Association (2003). Standard Methods for the Examination of water and Waste Water, 20th ed. Method $4500 \mathrm{E}$.

American Public Health Association (APHA), 1995. Standard Methods for Analysis of Water and Wastewater, $18^{\text {th }}$ edition. Port City Press, Baltimore,MD.

Bacchin, P;. A. Marty; P. Duru; M. Meireles; P. Aimar (2011). Colloidal surface interactions and membrane fouling: Investigations at pore scale Advances in Colloid and Interface Science 164, 2-11

Bilotta, G. S., \& Brazier, R. E. (2008). Understanding the influence of suspended solids on water quality and aquatic biota. Water research, 42(12), 2849-2861.

Bracchini, L, Loiselle, S.A., Tognazzi, A., Dattilo, A.M., Focardi, S.,Cózar, A., (2007). The optical qualities of shallow wetland lined bays in Lake Victoria. Wetl. Ecol. Manag., 15, 509-510

Castro-Gonz'alez Ml, M'endez-Armenta M.(2008) Heavy metals: implications associated to fish consumption. Environ Toxicol Pharmacol, 26: 263-271.

Chapman, D, (1996) Water Quality Assessments - A Guide to Use of Biota, Sediments and Water in Environmental Monitoring - Second Edition, University Press, Cambridge

Cózar, A., Bergamino, N., Mazzuoli, S., Azza, N., Bracchini, L., Dattilo, A., (2007). Relationships between wetland ecotones and inshore water quality in the Ugandan coast of Lake Victoria. Wetlands Ecology and Management, 15, 499- 507. doi:10.1007/s11273-007-9046-6.

de Zwart, A. H., de Boer, J., Vafei, A., Schotting R.J., Hassanizadeh, S.M. (2006). Experimental investigation of clogging processes in sandy aquifers near water supply wells, using X-ray chromatography. In preparation.

EPA, U. (2017). Secondary drinking water standards: Guidance for nuisance chemicals. Drinking Water Contaminants-Standards and Regulations.

Etale A, Drake DC. (2013):Industrial Pollution and Food Safety in Kigali, Rwanda. Int J Environ Res., 7 :403-406.

Grinning Planet. (2019) Polluted Seas: Major Bodies of Water/Areas with Serious Water Pollution Problems. http://grinningplanet.com/2005/07-26/polluted-seas.htm. Accessed 20 Aug 2019.

Grochowska J. and Tandyrak, R. (2009). The influence of the use of land on the content of calcium, magnesium, iron and manganese in water exemplified in three lakes in Olsztyn vincinity. Limnol. Rev., 9(1): 9-16.

Hakizimana P, Maniragaba A, Nshimiyimana FX. (2019): Assessment of Heavy Metals in Amaranthus Spinosus, Kigali, Rwanda. Int J Advanced Res Publ, $3: 7-12$.

Inglezakis, V.J., Stylianou, M.A., Gkantzou, D., and Loizidou, M.D., (2007): Removal of Pb (II) from aqueous solutions by using clinoptilolite and bentonite as adsorbents. Desalination, 210, pp 248-256

Kaaya, L. T., Day, J., \& Dallas, H. F. (2015). Tanzania River Scoring System (TARISS): a macro-invertebrate- based biotic index for rapid bio-assessment of rivers. African Journal of Aquatic Science, 40, 109-117.

Kasangaki, A., Babaasa, D., Efitre, J., McNeilage, A., \& Bitariho, R. (2006). Links between anthropogenic perturbations and benthic macroinvertebrate assemblages in Afro-montane forest streams in Uganda. Hydrobiologia, 563, 231-245. 
Kasangaki, A., Capman, L. J., \& Balirw, J. (2008). Land use and the ecology of benthic macroinvertebrate assemblages of high altitude rainforest streams in Uganda. Freshwater Biology, 53, 681-697.

Kennedy, K.K., Maseka, K.J. and Mbulo, M. (2018): Selected adsorbents for removal of contaminants from wastewater: Towards engineering clay minearls. Open journal of applied sciences 8, 355-369 http://doi.org/10.4236/ojapps.2018.8807

Lange, G-M, R. Hassan, K. Hamilton., 2003. Environmental Accounting in Action case studies from South Africa. Edward Elgor. UK.)

Liess, M., Schäfer, R., \& Schriever, C. (2008). The footprint of pesticide stress in communities-species traits reveal community effects of toxicants. Science of the Total Environment, 406, 484-490.

McDowell-Boyer, L.M.; R. Hunt, J.R.; Sitar, N. (1986) :Particle transport through porous media Water resources research 22(13) 1901-1921 https://doi.org/10.1029/WR022i013p01901

Ministry of Infrastructure, Republic of Rwanda, (MISR) . (2010). Rwanda National Policy and Strategy for Water Supply and Sanitation Services. Kigali: Ministry of Infrastructure.

Ministry of Natural Resources, Republic of Rwanda, MINIRENA. (2011). Water resources management sub-sector strategic plan (2011-2015). Kigali: MINIRENA.

Musinguzi, M. Ejiri, A.H. (2016) Trends in degradation of freshwater urban wetlands in Kampala Uganda a case study of Lubigi wetland. International journal of research in earth and environmental sciences4(3) http://www.ijsk.org/ijrees.html

National Institute of Statistics of Rwanda, NISR. (2014). Fourth Population and Housing Census, Rwanda 2012. Kigali: Ministry of Finance and Economic Planning, National Institute of Statistics of Rwanda.

National Institute of Statistics of Rwanda, NISR. (2015). Rwanda poverty profile, 2013/2014. Results of Integrated Household Living Conditions Survey. Kigali: National Institute of Statistics of Rwanda.

Ndayisaba, L., \& Mihale, M. J. (2015). Seasonal impacts of land use practices on water quality in Ngoma District, Rwanda. The African Resources Development Journal, 2, 1-20.

Nhapi I (2011) Assessment of Water Pollution Levels in the Nyabugogo Catchment, Rwanda The Open Environmental Engineering Journal 4(1):40-53 DOI: 10.2174/1874829501104010040

Nhapi I, Wali UG, Uwonkunda BK, Nsengimana H, Banadda N, Kimwaga R. (2011): Assessment of Water Pollution Levels in the Nyabugogo Catchment, Rwanda. Open Environ Eng J., 4: 40-53.

Nshimiyimana, F.; I. Nhapi, U. G. Wali, H. Nsengimana, N. Banadda, I. Nansubuga, F. Kansiime (2010) Assessment of Heavy Metal Pollution in a Trans-Boundary River: The Case of the Akagera River International journal of mathematics and computation 9 (D10) ISSN 0974-570X

Ogwok P, Muyonga JH, Sserunjogi ML.(2009): Pesticide residues and heavy metals in Nile perch (Lates niloticus) belly flap oil. Bull Environ Contam Toxicol., 82 : 529-933.

Omara, T.;Nteziyaremye, P.; Akaganyira, S.; Waswa, D. O., Nyambura,L. K.; Moraa D. N.; Jematia, B.K.; Ogwang, R.; Epiaka, S.M.; Jepchirchir, $A_{i ;}$ and Maiyo, A. (2020) Physicochemical Quality of Water and Health Risks Associated with the Consumption of the Extant African Lung Fish, Protopterus annectens from Nyabarongo and Nyabugogo Rivers, Rwanda: BMC research notes 202013 https://doi.org/10.1186/s13104-020-4939-z 
Pearson, J., \& McPhedran, K. (2008). A literature review of the non-health impacts of sanitation. Waterlines, 27, 48-61.

Potasznik, A., \& Szymczyk, S. (2015). Magnesium and calcium concentrations in the surface water and bottom deposits of a river-lake system. Journal of Elementology, 20(3).

Rahman MS, Molla AH, Saha N, Rahman A.(2012) Study on heavy metals levels and its risk assessment in some edible fishes from Bangshi River, Savar, Dhaka, Bangladesh. Food Chem., 134 : 1847-1854.

Ramachandran V, Fogler HS. (1999). Plugging by hydrodynamic bridging during flow of stable colloidal particles within cylindrical pores J Fluid Mech 385., 129-156. https://doi.org/10.1017/S0022112098004121

Rwanda Natural Resources Authority, RNRA. (2014). Consultancy services for the development of Rwanda's national water resources master plan, master plan report. Kigali: RNRA.

Sekomo, B. C., Uwamariya, V., Birori, M., Nkundimana, E., \& Nkuranga, J. B. (2012). Water quality monitoring in Rwanda. Kigali: National University of Rwanda.

Sekomo, C.B., Rousseau, D.P.L., \& Lens, P.N.L., (2012a). Use of Gisenyi Volcanic Rock for Adsorptive Removal of $\mathrm{Cd}(\mathrm{II}), \mathrm{Cu}(\mathrm{II}), \mathrm{Pb}(\mathrm{II})$, and $\mathrm{Zn}(\mathrm{II})$ from Wastewater. Water Air and Soil Pollution

Sen Gupta, P. (2013). Potential health impacts of hard water. International journal of preventive medicine, 4(8), 866.

Sen, T. K., and Khilar, K. C. (2006). Review on subsurface colloids and colloid-associated contaminant transport in saturated porous media. Advances in Colloid and Interface Science, 119(2-3), 71-96.

Singh, N., Nagpal, G., Agrawal, S. and Rachina (2018). Water purification by using various adsorbents: A review. Environmental technology and innovation 11, 187-240. http://doi.org/10.1616/j.eti.2018.05.006.

Sutherland, B. A., Meyer, J. L., \& Gardiner, E. P. (2002). Effects of land cover on sediment regime and fish assemblage structure in four southern Appalachian streams. Freshwater Biology, 47, 1791-1805.

Syafalni, Rohana Abdullah, Ismail Abustan, Aimi Nadiah Mohd Ibrahim (2013). Wastewater treatment using bentonite, the combinations of bentonite-zeolite, bentonite-alum, and bentonitelimestone as adsorbent and coagulant International Journal of Environmental Sciences Volume 4 No.3, 2013391

UNEP (2008) Vita Water graphics, 2nd edition. An Overview of the State of the World's Fresh and Marine Waters. URL: http://www.unep.org/dewa/vitalwater/article83.html (Accessed 16 May 2020)

U.S. Environmental Protection Agency, Eutrophication: http://www.epa.gov/maia/html/eutroph.html

U.S. Environmental Protection Agency, National Nutrient Guidance: http://www.epa.gov/ost/criteria/nutrient/guidance/

van Olphen, H. (1977), An Introduction to Clay Colloid Chemistry, Wiley Interscience, New York, NY, USA, 2nd edition, 1977.

Verma, A., Wei, X., \& Kusiak, A. (2013). Predicting the total suspended solids in wastewater: a data-mining approach. Engineering Applications of Artificial Intelligence, 26(4), 1366-1372. 
Water Aid Rwanda. (2016). WaterAid Rwanda Country Programme Strategy: 2016-2021. Kigali: WaterAid http://www.wateraid.org/google-search?query=rwanda\&refinement=Publications. Accessed January $20,2018$.

Water for Growth Rwanda, WFGR. (2017). Muvumba Catchment Plan Summary-integrating land and water resources management through joint performance contracts. Kigali: MINIRENA http://www.water.rw/wpcontent/uploads/2017/05/Muvumba-Catchment-Plan-Summary-1.pdf. Accessed April 2, 2020.

Water Resources Information Bulletin No 06 for December 2012"

World Health Organization, WHO (2004). Guidelines for Drinking Water Quality, vol. 1, 3 rd ed. World Health Organization, Geneva, Switzerland.

World Health Organization, WHO (2008). Guidelines for Drinking Water Quality, Incorporating the first and second Addenda. vol. 1, 3rd ed. World Health Organization, Geneva, Switzerland. 20. Oeteman, B.C.J (1980).

World Health Organization, WHO. (2017). Drinking-water fact sheet. Geneva: WHO http://www.who.int/mediacentre/factsheets/fs391/en. Accessed January 20, 2018.

World Water Assessment Programme. The United Nations World Water Development Report: Water for People, Water for Life; UNESCO: Paris, France, 2003.

Wronski, T., Dusabe, M. C., Apio, A., Hausdorf, B., \& Albrecht, C. (2015b). Biological assessment of water quality and biodiversity in Rwandan rivers draining into Lake Kivu. Aquatic Ecology, 49, 309-320.

\section{Conflicts of Interest}

We hereby declare there is no conflict of interests that exist. This work should remain open to everyone who wishes to access it. 